\title{
Bullying involvement and substance use among Brazilian adolescent students
}

\author{
Natalia Woolley ${ }^{1}$ and James Macinko ${ }^{2}$
}

Suggested citation Woolley N, Macinko J. Bullying involvement and substance use among Brazilian adolescent students. Rev Panam Salud Publica. 2018;42:e95. https://doi.org/10.26633/RPSP.2018.95

\begin{abstract}
Objective. Although bullying involvement has been associated with adolescent substance use, most of this evidence comes from high-income countries. Little is known about substance use among perpetrator-victims in low- and middle-income countries. This study explores the asso-ciation between types of bullying involvement and adolescent substance use in Brazil.

Methods. Data for this cross-sectional study came from the 2015 Pesquisa Nacional de Saúde do Escolar [National Adolescent School-based Health Survey] (PeNSE), a nationwide school-based survey of Brazilian ninth graders. Substance use was analyzed as any substance use (i.e., use of alcohol, cigarettes, or marijuana in the previous 30 days) and substance co-use (i.e., use of all three substances). Logistic regression analyses were conducted, and adjusted odds ratios (aORs) were calculated, adjusting for demographic characteristics and student loneliness.

Results. Odds of any substance use for bullying perpetrators-only and for perpetrator-victims, respectively, were significantly higher compared to no bullying involvement ( $a \mathrm{OR}=$ $2.99,95 \% C I=2.71-3.30$ and $a O R=2.52,95 \% C I=2.31-2.75)$. Adjusted odds of substance co-use were also significantly higher among perpetrators-only and perpetrator-victims $(a \mathrm{OR}=$ $4.04,95 \% \mathrm{CI}=3.05-5.35$ and $a O R=3.49,95 \% \mathrm{CI}=2.71-4.51$, respectively). Victimizationonly was associated with a $14 \%$ increase in the odds of any substance use (aOR $=1.14,95 \%$ $C I=1.07-1.22$ ).

Conclusions. The results underscore the complex relationship between adolescent bullying involvement and substance use. Findings also indicate the type of bullying involvement, as well as demographic and psychological factors, should be taken into consideration when assessing adolescent health-risk behaviors.
\end{abstract}

Keywords Adolescent; bullying; substance-related disorders; Brazil.

A common experience for many adolescents, bullying can have lifelong repercussions. Worldwide estimates indicate that approximately one in three

\footnotetext{
Department of Community Health Sciences, Fielding School of Public Health, University of California Los Angeles, Los Angeles, California, United States of America. Send correspondence to Natalia Woolley at natalia.woolley@ucla.edu
}

adolescent males, and one in four adolescent females, have been the target of bullying (1). Longitudinal studies also show that bullying victimization during

\footnotetext{
2 Departments of Health Policy and Management and Community Health Sciences, Fielding School of Public Health, University of California Los Angeles, Los Angeles, California, United States of America.
}

childhood and adolescence is associated with higher rates of mental health problems later in life (2), while adolescent bullies are more likely to engage in serious violent behaviors in adulthood (3). Thus, the widespread prevalence of bullying, coupled with its potential negative impacts on adolescent development, have made the issue a global public health concern (1). 
Bullying is a complex phenomenon and has been categorized according to the type and medium of aggression, including physical (e.g., slapping and pushing); verbal (e.g., teasing and swearing at someone); relational (e.g., exclusion) aggression (4); and cyberbullying (posting negative comments on social media and cyberstalking) (5). Direct bullying involvement is typically understood to be a continuum with three interconnected groups: a) victim-only; b) perpetrator-only; and c) perpetratorvictim (4). Moreover, indirect bullying involvement has also been analyzed as researchers have sought to understand how bystanders can promote or prevent instances of bullying (5).

Individuals whose physical and mental well-being has been disturbed may engage in a variety of coping behaviors $(6,7)$. For example, adolescents involved in bullying can develop healthy coping strategies to reduce stress and anxiety by reaching out to friends for social support (8). However, some may instead engage in unhealthy coping behaviors such as substance use (e.g., alcohol, cigarettes, or marijuana).

Given the negative health impacts of substance use $(9,10)$ and bullying involvement $(2,3)$-and their potential interplay-emerging research has attempted to elucidate how different types of bullying involvement might be associated with adolescent substance use (11-13). However, this research has been primarily carried out in high-income countries, even as surveys indicate bullying might be even more pervasive in low- and middle-income countries (1). In low- and middle-income settings, the higher prevalence of youth violence, lower levels of public awareness, and limited resources to address those problems highlight the importance of understanding bullying involvement and its ramifications in those situations.

There is limited knowledge on bullying in Brazil, a middle-income country home to approximately 34 million adolescents (14). Two major studies using nationally representative data have provided somewhat contradictory results. In the first, bullying victimization was positively associated with regular cigarette smoking only (15). The second study found that bullying perpetrators were more likely to report alcohol, cigarette, and illicit drug use than were nonperpetrators (16). However, neither study assessed substance use among those who were both bullying victims and aggressors, nor did they investigate co-use of multiple substances, a behavior that might put adolescents at even higher risk of failing at school (17) and experimenting with illicit drugs $(18,19)$.

This study intends to fill this gap in knowledge by using a nationally representative sample to conduct a quantitative analysis of the association between the most common forms of substance use and each type of direct bullying involvement among Brazilian adolescent students.

\section{METHODS}

\section{Data source}

Data for this cross-sectional study were obtained from the Pesquisa Nacional de Saúde do Escolar [National Adolescent School-based Health Survey] (PeNSE) (20). The PeNSE is a triennial, nationwide survey of students attending ninth grade in Brazil (equivalent to the ninth grade in the school system in the United States of America). The survey is administered in Portuguese, and is modeled after the Global School-based Student Health Survey (GSHS) and the Youth Risk Behavior Surveillance System (YRBSS) (21). The 2015 PeNSE survey included 102301 students sampled from 3040 public and private schools. Data collection was conducted using researcher-provided smartphones without survey staff intermediation, and took place between April and September 2015 (22). The final response rate was $85.9 \%$, taking into consideration both refusals and student absences during the survey day (22).

\section{Variable description}

The independent variable, bullying involvement, captured instances of direct bullying involvement. Students were asked two questions on this topic. The first was if they had acted in ways that intimidated, humiliated, offended, or hurt someone else's feelings in the previous 30 days (yes/no). The second was if they had ever suffered bullying victimization (without a specific time interval), using the English-language term "bullying." Three response options were provided to ensure that students knew the meaning of the English term: "yes," "no," and
"I don't know what 'bullying' is." Most students were familiar with the term, as evidenced by the small percentage of adolescents who chose the third option $(1.7 \%)$, and this small group was not included in the analysis. These two questions were combined to generate one categorical variable with four types of bullying involvement: none, victim-only, perpetrator-only, and perpetrator-victim.

The dependent variable, substance use, was based on three survey questions about the number of the past 30 days in which students had used alcohol, cigarettes, or marijuana. Students who replied zero days of alcohol, cigarettes, and marijuana use were coded as nonusers, and those who replied one or more days were coded as current users. Substance use was further operationalized as: 1) any substance use (yes; no) and 2) substance co-use (yes; no), which measured whether adolescents had used all three substances.

Bullying involvement and substance use may be affected by such other factors as age, sex, race, and perceived loneliness $(4,15,23-25)$. This study included multiple control variables including sex (male; female), age (six categories: 13 or younger; $14 ; 15 ; 16 ; 17$; and 18 or older), geographic region (North; Northeast; South; Southeast; and Center-West), and school type (public; private). The variable race (white; black; mixed race; and other) was also included as a demographic control, and Asian and indigenous students were combined into the "other" category due to their small numbers $(4.49 \%$ and $3.75 \%$ of the total sample, respectively). Lastly, one variable related to students' perception of loneliness was included: frequently felt lonely in the previous 12 months. Loneliness is often a symptom of mental health problems, such as depression (26), which can be a risk factor for bullying involvement and substance use (27). Loneliness can be also be a risk factor in itself since peer groups can protect adolescents against bullying victimization (25) or even support and reinforce bullying aggression (28). Adolescents who reported never or rarely feeling lonely were coded as "no," and answers ranging from sometimes to always were coded as "yes."

\section{Analytical plan}

Univariate and bivariate descriptive statistics for all variables were conducted 
as part of the initial exploratory analysis. Bivariate analyses were conducted using prevalence ratios and 95\% confidence intervals (95\% CIs). Logistic regression analyses were carried out for each of the substance use variables, and adjusted odds ratios (aORs) and confidence intervals were estimated. Interaction terms between main explanatory variables were tested. Only the interaction between sex and loneliness improved model fit, and therefore it was assessed for both models. Adjusted predicted probabilities of the interaction terms were calculated and plotted to visualize their potential as modifying factors in the relationship between bullying involvement and substance use. Multiple post-estimation analyses were conducted to assess model fit, including Pearson $\chi^{2}$ goodness-of-fit tests and inspection of receiver operating characteristic (ROC) curves, in which values near 0.70 or above were considered acceptable (29). In addition, model specification tests were conducted using the "linktest" command in the Stata software (30).

All analyses were adjusted for the survey's complex sample design by using the "svy" command from Stata 14.0 (StataCorp LP, College Station, Texas, United States). Survey weights provided population estimates for all noninstitutionalized ninth grade students in Brazil. Raw survey data, publicly available from the Brazilian Institute of Geography and Statistics (IBGE) website, contained de-identified student information to ensure participant privacy. For this reason, this study was considered exempt from human subjects review.

\section{RESULTS}

Females comprised about half of all the students, and the majority $(70.8 \%)$ of the ninth graders were either 14 or 15 years old (Table 1 ). About $1.2 \%$ of students in ninth grade were 18 years or older, in line with Brazil's higher rates of educational delay as compared to countries of the Organization for Economic Cooperation and Development (OECD) (31). Similar to the general Brazilian population, most students reported being mixed race $(43.1 \%)$, followed by white $(36.2 \%)$ and black (13.4\%). The majority of students also attended public schools $(85.5 \%)$ and lived in the Southeast or Northeast regions of the country $(71.1 \%)$. Approximately two out of five students

TABLE 1. Demographic characteristics, bullying involvement, and substance use among Brazilian adolescent students, with unweighted frequencies, weighted percentages, and 95\% confidence intervals (95\% Cls), National Adolescent Schoolbased Health Survey (PeNSE) 2015

\begin{tabular}{|c|c|c|c|}
\hline Student characteristic & Unweighted frequency & Weighted percentage & $95 \% \mathrm{Cl}$ \\
\hline \multicolumn{4}{|l|}{$\overline{\operatorname{Sex}}$} \\
\hline Female & 52782 & 51.3 & $50.7-51.8$ \\
\hline Male & 49290 & 48.7 & $48.2-49.3$ \\
\hline \multicolumn{4}{|l|}{ Race/Ethnicity } \\
\hline White & 33775 & 36.2 & $35.6-36.7$ \\
\hline Black & 12849 & 13.4 & $13.0-13.8$ \\
\hline Mixed race & 46935 & 43.1 & $42.5-43.6$ \\
\hline Other ${ }^{\mathrm{a}}$ & 8405 & 7.4 & 7.1-7.7 \\
\hline \multicolumn{4}{|l|}{ Age } \\
\hline 13 or younger & 17260 & 18.3 & $17.8-18.7$ \\
\hline 14 & 51611 & 51.0 & $50.5-51.6$ \\
\hline 15 & 20864 & 19.8 & $19.4-20.2$ \\
\hline 16 & 7873 & 7.2 & $6.9-7.5$ \\
\hline 17 & 3040 & 2.5 & $2.4-2.7$ \\
\hline 18 or older & 1424 & 1.2 & $1.1-1.3$ \\
\hline \multicolumn{4}{|l|}{ Region } \\
\hline North & 23937 & 9.6 & $9.5-9.7$ \\
\hline Northeast & 36334 & 27.7 & $27.5-27.9$ \\
\hline Southeast & 17772 & 43.4 & $43.1-43.7$ \\
\hline South & 9850 & 11.9 & $11.7-12.0$ \\
\hline Center-West & 14179 & 7.5 & 7.4-7.6 \\
\hline \multicolumn{4}{|l|}{ School type } \\
\hline Private & 20918 & 14.5 & $14.1-14.8$ \\
\hline Public & 81154 & 85.5 & $85.2-85.9$ \\
\hline \multicolumn{4}{|l|}{ Frequently felt lonely } \\
\hline Yes & 45462 & 43.9 & $55.5-56.6$ \\
\hline No & 56206 & 56.1 & $43.4-44.5$ \\
\hline \multicolumn{4}{|l|}{ Any substance use } \\
\hline Yes & 77637 & 25.5 & $25.0-26.0$ \\
\hline No & 24240 & 74.5 & $73.9-74.9$ \\
\hline \multicolumn{4}{|l|}{ Substance co-use } \\
\hline Yes & 1930 & 2.0 & $1.8-2.1$ \\
\hline No & 99947 & 98.0 & $97.9-98.2$ \\
\hline \multicolumn{4}{|l|}{ Bullying involvement } \\
\hline None & 44222 & 43.6 & $43.0-44.1$ \\
\hline Victim-only & 37034 & 36.9 & $36.3-37.4$ \\
\hline Perpetrator-only & 7533 & 8.1 & 7.8-8.4 \\
\hline Perpetrator-victim & 10991 & 11.5 & $11.1-11.9$ \\
\hline
\end{tabular}

Source: Prepared by the authors from data from the Brazilian Institute of Geography and Statistics (22). a The "other" race/ethnicity category includes Asian and indigenous students.

(43.9\%) had experienced frequent feelings of loneliness in the previous 12 months.

One in four adolescents (25.5\%) used either alcohol, cigarette, or marijuana in the previous 30 days, while only a small percentage $(2.0 \%)$ used all three substances during that time period (Table 1). In addition, a majority of the students had some type of direct bullying involvement $(56.5 \%)$. The most common type of bullying involvement was as victim-only
$(36.9 \%)$, followed by perpetrator-victim $(11.5 \%)$ and perpetrator-only $(8.1 \%)$.

Unadjusted odds of any substance use among perpetrators-only were almost three times the odds for adolescents not involved in bullying (OR $=2.98,95 \% \mathrm{CI}$ = 2.71-3.28) (Table 2). Adjusting for demographic factors, region, and loneliness did not alter the statistical significance of the odds of substance use associated with bullying involvement. The final model included a statistically significant 
TABLE 2. Predictors of any substance use among Brazilian adolescent students. Logistic regression odds ratios (ORs) ${ }^{\mathrm{a}}$ and $95 \%$ confidence intervals (Cls), National Adolescent School-based Health Survey (PeNSE) 2015

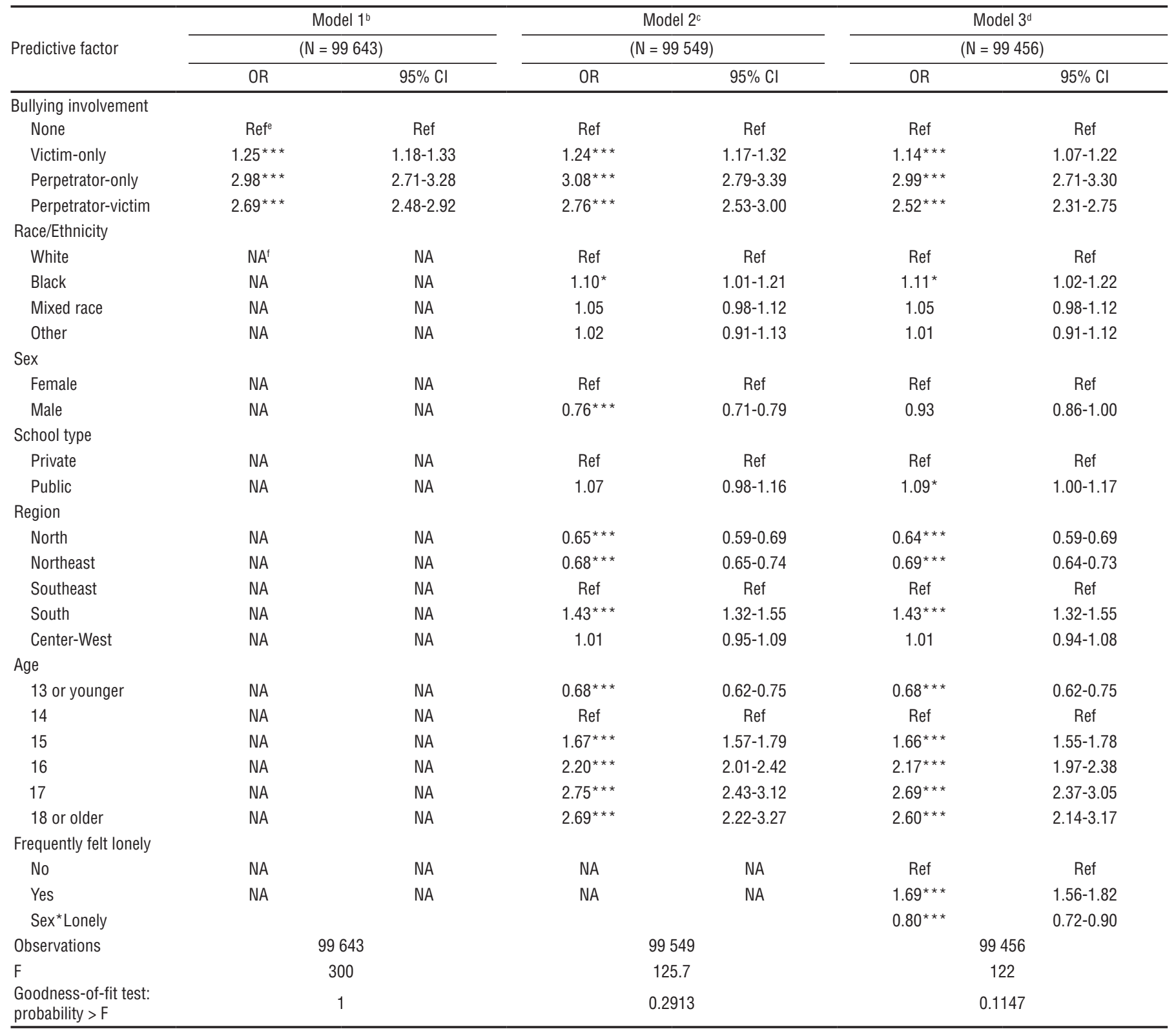

Source: Prepared by the authors from data from the Brazilian Institute of Geography and Statistics (22).

$a^{*}=p<0.05 ;{ }^{* *}=p<0.01 ; * * *=p<0.001$.

${ }^{b}$ Model $1=$ independent variable only (i.e., bullying involvement).

${ }^{c}$ Model 2 = independent variable plus adjustments for race/ethnicity, sex, school type, region, and age.

${ }^{\mathrm{d}}$ Model 3 = independent variable plus adjustments for race/ethnicity, sex, school type, region, age, loneliness, and the interaction between loneliness and sex.

${ }^{\mathrm{e}}$ Ref $=$ reference.

${ }^{\dagger} \mathrm{NA}=$ not applicable.

interaction term between sex and student frequency of feeling lonely.

Adjusted odds of any substance use was higher among students involved in bullying than those with no involvement. However, the magnitude of the difference varied according to the type of bullying involvement. For instance, odds of any substance use among victims-only were $14 \%$ higher compared to students not involved in bullying $(\mathrm{aOR}=1.14$, 95\% CI = 1.07-1.22) (Table 2). In comparison, the odds of any substance use for perpetrator-only were around three times the odds of students with no involvement $(\mathrm{aOR}=2.99,95 \% \mathrm{CI}=2.71$ 3.30). Furthermore, odds of any substance use among perpetrator-victims
$(\mathrm{aOR}=2.52,95 \% \mathrm{CI}=2.31-2.75)$ were closer to the odds for perpetrators-only than victims-only.

Statistically significant differences in the adjusted odds of any substance use were also noted between members of different racial/ethnic groups, public and private school students, geographic regions, and age groups (Table 2). 
FIGURE 1. Covariate-adjusted predicted probability of any substance use for adolescent students in each type of bullying involvement, according to loneliness experience and sex, National Adolescent School-based Health Survey (PeNSE) 2015

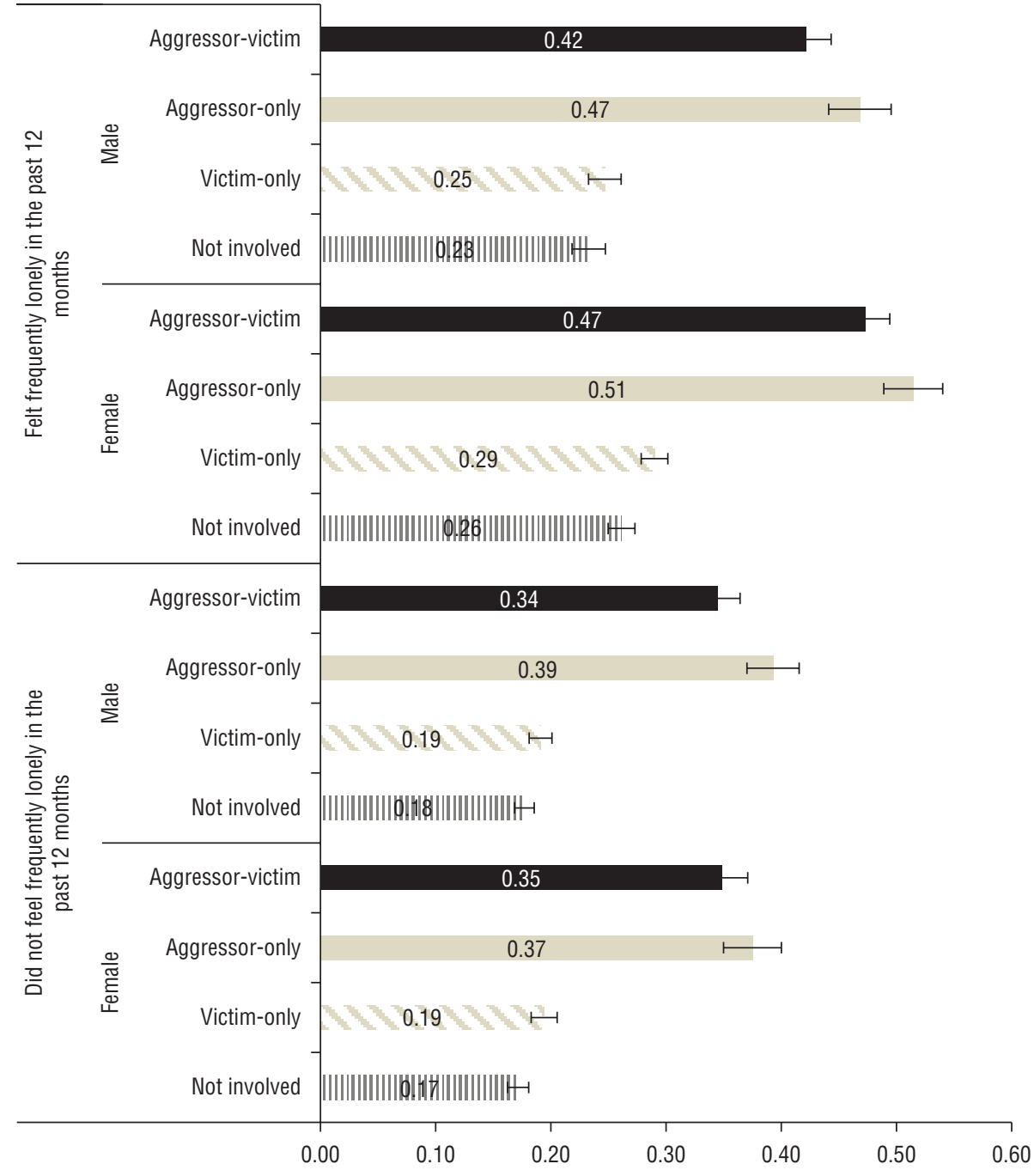

Source: Prepared by the authors from data from the Brazilian Institute of Geography and Statistics (22).

For example, after adjusting for all the variables in the final model, odds of any substance use among black adolescents were $11 \%$ higher than for whites $(\mathrm{aOR}=$ $1.11,95 \% \mathrm{CI}=1.02-1.22)$. Moreover, the significance of the interaction term between sex and loneliness $(\mathrm{aOR}=0.80$, $95 \% \mathrm{CI}=0.72-0.90$ ) suggests that they are modifying factors in the relationship between bullying involvement and substance use.

Figure 1 shows covariate-adjusted predicted probabilities of any substance use for adolescents in each type of bullying involvement, according to loneliness experience and sex. When all covariates are adjusted, adolescents who frequently felt lonely had higher predicted probabilities of any substance use compared to those who did not. However, these differences were more substantial among females. For example, the highest rates of substance use (over 50\%) are observed for female aggressors who felt loneliness, followed closely by female aggressor-victims. In contrast, substance use among adolescents (of either sex) who did not feel lonely and were not engaged in bullying, at around $18 \%$, was lower than for the sample overall.

For victims-only as compared to those uninvolved, both the unadjusted and adjusted models yielded nonsignificant odds of substance co-use (respectively, $\mathrm{OR}=1.08,95 \% \mathrm{CI}=0.84-1.39$ and $\mathrm{OR}=0.98,95 \% \mathrm{CI}=0.76-1.27$ ) (Table 3). Odds for perpetrators-only and perpetrator-victims were statistically higher compared to noninvolved adolescents across all three models assessed. Odds of substance co-use for perpetrators-only were about four times the odds of noninvolved adolescents, after accounting for demographic factors and loneliness (aOR $=4.04,95 \% \mathrm{CI}=3.05-5.35)$. The adjusted odds of substance co-use for perpetrator-victims were similar $(\mathrm{aOR}=3.49,95 \%$ $\mathrm{CI}=2.71-4.51)$. An interaction term between sex and loneliness was not statistically significant $(\mathrm{aOR}=0.80,95 \%$ $\mathrm{CI}=0.54-1.18$ ) and was not included in the final model.

Race and school type were not statistically associated with adolescent substance co-use after adjusting for bullying involvement, other demographic factors, and loneliness. Adolescents in the North and Northeast regions had lower adjusted odds of substance co-use compared to adolescents in the Southeast. In addition, odds of substance co-use among adolescent who frequently felt lonely was $69 \%$ higher than for those who did not experience frequent loneliness $(\mathrm{aOR}=1.69,95 \% \mathrm{CI}=1.39-2.06)$.

\section{DISCUSSION}

These results underscore the complex relationship between bullying involvement and substance use among adolescents. Two different patterns were observed. In the first, all adolescents involved in bullying, regardless of the type of involvement, were more likely to have engaged in any substance use, compared to those not involved in bullying. In the second, perpetrators-only and perpetrator-victims were more likely to engage in substance co-use than were victims-only and those not involved.

Although adolescents involved in bullying were not directly asked about the reasons why they engaged in substance use, the variation in patterns between any substance use and substance co-use may indicate different drivers for such behaviors. For instance, use of any substance might be associated with coping with stress, as suggested by the Transactional Model of Stress and Coping (7). This was the case in a study of alcohol use and adolescent bullying involvement in Switzerland (12), where researchers found that coping motives were associated with overall higher levels of alcohol use across all types of bullying involvement, although that association was only consistently 
TABLE 3. Predictors of substance co-use among Brazilian adolescent students, with logistic regression odds ratios (ORs) ${ }^{\mathrm{a}}$ and 95\% confidence intervals (Cls), National Adolescent School-based Health Survey (PeNSE) 2015

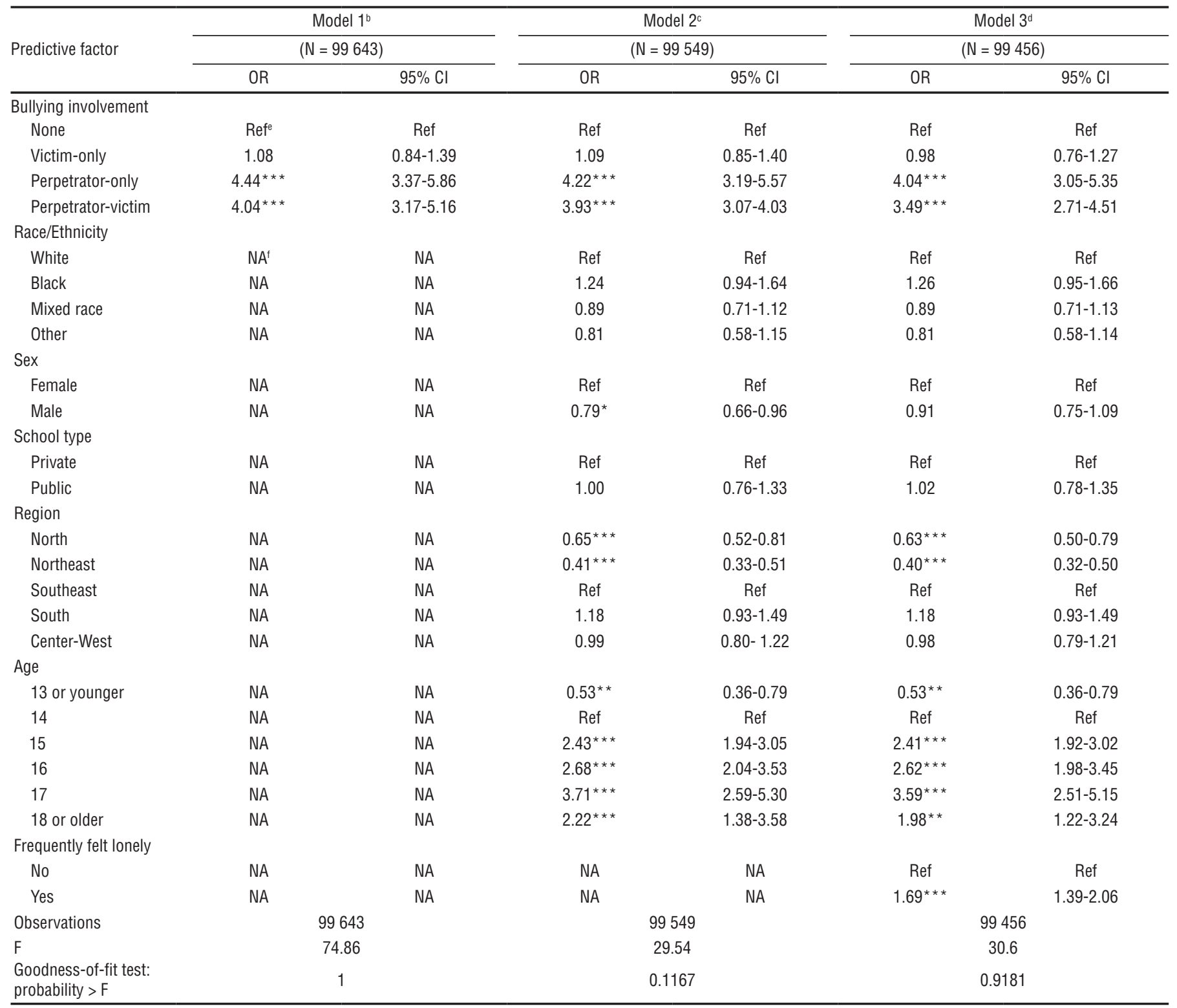

Source: Prepared by the authors from data from the Brazilian Institute of Geography and Statistics (22).

${ }^{a *}=p<0.05 ;{ }^{* *}=p<0.01 ;{ }^{* * *}=p<0.001$.

${ }^{\mathrm{b}}$ Model $1=$ independent variable only (i.e., bullying involvement).

${ }^{\mathrm{c}}$ Model 2 = independent variable plus adjustments for race/ethnicity, sex, school type, region, and age.

${ }^{\mathrm{a}}$ Model 3 = independent variable plus adjustments for race/ethnicity, sex, school type, region, age, loneliness, and the interaction between loneliness and sex.

${ }^{\text {e }}$ Ref $=$ reference

${ }^{\dagger} \mathrm{NA}=$ not applicable.

significant for females. On the other hand, substance co-use, which indicates a potentially more serious substance use problem, might be associated with a broader context of violence, aggression, and delinquency that does not necessarily include victim-only bullying. For instance, researchers have suggested that adolescents engaged in violent or aggressive actions might be more likely to establish relationships with other youths who also participate in deviant behaviors, including substance use $(32,33)$.

Sex and loneliness were significant modifying factors in the relationship between bullying involvement and substance use. The likelihood of any substance use was higher among those who frequently felt lonely, irrespective of the sex. In addition, perpetrators and perpetrator-victims were more likely to engage in any substance use as compared to victims-only and noninvolved adolescents. However, among females, differences in the likelihood of any substance use according to loneliness were 
more pronounced than in males. These results are consistent with findings from a study of adolescents in the United States that noted that bullying victimization was associated with both depression and substance use among females, but only with depression among males (34). Higher rates of substance use among females involved in bullying in Brazil are also similar to findings from a Finnish study in which female bullying aggressors reported higher rates of excessive drinking, anxiety, and depressive symptoms than males did (35). These results indicate adolescent females might be more susceptible to substance use, especially if they are involved in bullying and frequently feel lonely.

In Brazil, as in the United States, the negative consequences of bullying became part of the national debate following a major tragedy. In 2011 a man who allegedly had been a bullying victim during adolescence entered the school in Rio de Janeiro that he had previously attended and killed 12 adolescents there (36). In 2015, President Dilma Roussef signed into law the National Program Against Systematic Intimidation (Bullying), which provided a legal definition of bullying and outlined multiple actions to identify and prevent bullying at various levels (e.g., individuals, families, schools, and broader society) (37). Notably, the program, for which implementation began in early 2016, acknowledges different types of bullying involvement and supports psychological attention not only for the victims, but also for aggressors. Future analysis of the effectiveness of this policy should investigate changes in rates of substance use among adolescents involved in bullying in order to assess if additional psychological support has been effective in lowering these rates.

Our findings are in line with results from high-income countries that suggest that bullying perpetrators are more likely to engage in multiple problem behaviors. It is also important to note that research in high-income countries has linked bullying aggression to violent actions later in life. In one longitudinal study in the Pacific Northwest of the United States, bullying aggression in the fifth grade was a predictor of violent behavior (e.g., badly beating someone, or threatening someone with a weapon) at age 21 (3). Therefore, bullying prevention should be a key element in antiviolence policies, especially in countries with extreme rates of violent incidents, such as Brazil (31). Furthermore, our results indicate that bullying prevention efforts should address other problems behaviors such as substance use, in order to better target atrisk youth and provide more effective interventions.

\section{Limitations}

One fundamental limitation of any cross-sectional study design is that it cannot be used to ascertain causation or rule out reverse causality. Therefore, this analysis focuses on describing the scope of the problem and understanding the association between variables. Although it is not possible to completely rule out reverse causation, most existing evidence suggests that substance use is a consequence (not the cause) of adolescent mental health and relationship problems $(3,38)$.

Survey sampling and administration methods also presented some limitations that should be mentioned. For instance, since the survey was administered in the classroom, it is possible that students with more severe problems with substance use and bullying involvement were absent from school on the survey day, or had dropped out of school altogether. As a result, the survey may have failed to capture the most vulnerable adolescents. Moreover, bullying and substance are sensitive topics and therefore students may have underreported their occurrences.

There are also a few limitations related to the survey content. First, since the question on bullying victimization did not provide a definition or examples of this behavior, students' self-report of bullying experiences may not have been completely in line with the most common definition of bullying (i.e., repeated victimization over a period of time marked by an imbalance of power) (39). In addition, the survey question on bullying perpetration only captured the verbal dimension of direct bullying aggression, and this was assessed only for a limited period (previous 30 days). On the other hand, bullying victimization was assessed in a more general way and without a specific time range, and thus may have encompassed instances of physical, relational, and even cyber aggression. Therefore, prevalence of bullying perpetration in Brazil might be much higher than the present estimates, and the findings may have underestimated the association between bullying involvement and substance use. Nevertheless, the statistically significant association between substance use and perpetrators-only and perpetrators-victims noted in this study contributes to the understanding that adolescent bullying aggression is related to substance use.

\section{Conclusions}

Our results show that a substantial proportion of adolescent Brazilians in ninth grade had some type of direct experience with bullying. In addition, bullying involvement and substance use were related in two distinct patterns. In the first, odds of any substance use were higher among adolescents involved in any type of bullying, as compared to those not involved. In the second, odds of substance co-use were higher among adolescents involved in bullying aggression, either as perpetrator-victims or perpetrators-only, versus nonaggressors. These findings are generally in line with research in high-income countries that highlights bullying involvement as a risk factor for substance use and that indicates that perpetrator-victims' substance use patterns are more comparable to those of perpetrators-only than they are to those of victims-only.

In conclusion, the type of bullying involvement can be an important factor when assessing health-risk behaviors among adolescents, since they are likely to co-occur. Moreover, bullying prevention efforts should provide tailored support to both victims and aggressors, and consider the unique needs of those at the intersection of aggression and victimization. Finally, it is possible that effective bullying prevention efforts have the potential to impact a broader context of violence and therefore provide a unique intervention opportunity.

Funding. This research was made possible thanks to the financial support from the University of California Los Angeles, Graduate Summer Research Mentorship Program.

\section{Conflicts of interest. None declared.}

Disclaimer. Authors hold sole responsibility for the views expressed in the manuscript, which may not necessarily reflect the opinion or policy of the RPSP/ PAJPH or PAHO. 


\section{REFERENCES}

1. Elgar FJ, McKinnon B, Walsh SD, Freeman J, D. Donnelly P, de Matos MG, et al. Structural determinants of youth bullying and fighting in 79 countries. J Adolesc Health. 2015;57(6):643-50.

2. Copeland WE, Wolke D, Angold A, Costello EJ. Adult psychiatric outcomes of bullying and being bullied by peers in childhood and adolescence. JAMA Psychiatry. 2013;70(4): 419-26.

3. Kim MJ, Catalano RF, Haggerty KP, Abbott RD. Bullying at elementary school and problem behaviour in young adulthood: a study of bullying, violence and substance use from age 11 to age 21. Crim Behav Ment Health. 2011;21(2):136-44.

4. Wang J, Iannotti RJ, Nansel TR. School bullying among adolescents in the United States: physical, verbal, relational, and cyber. J Adolesc Health. 2009;45(4):368-75.

5. Slonje R, Smith PK. Cyberbullying: another main type of bullying? Scand J Psychol. 2008;49(2):147-54.

6. Lazarus RS, Folkman S. Transactional theory and research on emotions and coping. Eur J Pers. 1987;1(3):141-69.

7. Brenner AB, Zimmerman MA, Bauermeister JA, Caldwell CH. The physiological expression of living in disadvantaged neighborhoods for youth. J Youth Adolesc. 2013;42(6):792-806.

8. Dumont M, Provost MA. Resilience in adolescents: protective role of social support, coping strategies, self-esteem, and social activities on experience of stress and depression. J Youth Adolesc. 1999;28(3): 343-63.

9. Bava S, Jacobus J, Thayer RE, Tapert SF. Longitudinal changes in white matter integrity among adolescent substance users. Alcohol Clin Exp Res. 2013;37 Suppl 1:E181-9.

10. World Health Organization. Adolescents: health risks and solutions 2016. Available from: http://www.who.int/mediacentre/ factsheets/fs345/en/ Accessed on 30 June 2017.

11. Vieno A, Gini G, Santinello M. Different forms of bullying and their association to smoking and drinking behavior in Italian adolescents. J Sch Health. 2011;81(7):393-9.

12. Archimi A, Kuntsche E. Do offenders and victims drink for different reasons? Testing mediation of drinking motives in the link between bullying subgroups and alcohol use in adolescence. J Addict Behav. 2014; 39(3):713-6.

13. Ringwalt $C$, Shamblen $S$. Is there an association between adolescent bullying victimization and substance abuse? J Drug Educ. 2012;42(4):447-67.

14. Instituto Brasileiro de Geografia e Estatística. Censo Demográfico 2010. Características da população e dos domicílios. Resultados do universo. Available from: http://www.brasileirosno mundo.itamaraty.gov.br/a-comunidade/ estimativas-populacionais-dascomunidades/estimativas-do-ibge/censodemografico-ibge-2010.pdf. Accessed on 10 July 2017.

15. Malta DC, do Prado RR, Dias AJ, Mello FC, Silva MA, da Costa MR, et al. Bullying and associated factors among Brazilian adolescents: analysis of the National Adolescent School-based Health Survey (PeNSE 2012). Rev Bras Epidemiol. 2014;17 Suppl 1:131-45.

16. de Oliveira WA, Silva MAI, da Silva JL, de Mello FCM, do Prado RR, Malta DC. Associations between the practice of bullying and individual and contextual variables from the aggressors' perspective. J Pediatr (Rio J). 2016;92(1):32-9.

17. Kelly AB, Evans-Whipp TJ, Smith R, Chan GC, Toumbourou JW, Patton GC, et al. A longitudinal study of the association of adolescent polydrug use, alcohol use and high school non-completion. Addiction. 2015;110(4):627-35.

18. Tomczyk S, Hanewinkel R, Isensee B. Multiple substance use patterns in adolescents-A multilevel latent class analysis. Drug Alcohol Depend. 2015;155:208-14.

19. Maldonado-Molina MM, Lanza ST. A framework to examine gateway relations in drug use: an application of latent transition analysis. J Drug Issues. 2010;40(4): 901-24.

20. Instituto Brasileiro de Geografia e Estatística. Pesquisa Nacional de Saúde do Escolar [dataset]. Rio de Janeiro: IBGE; 2015.

21. Instituto Brasileiro de Geografia e Estatística. Pesquisa Nacional de Saúde do Escolar 2009. Available from: https://biblioteca.ibge.gov.br/visualizacao/livros / liv43063.pdf Accessed on 10 July 2017.

22. Instituto Brasileiro de Geografia e Estatística. Pesquisa Nacional de Saúde do Escolar 2015. Available from: https://biblioteca.ibge.gov.br/visualizacao/livros / liv97870.pdf Accessed on 15 June 2017.

23. Smith PK, Mahdavi J, Carvalho M, Fisher S, Russell S, Tippett N. Cyberbullying: its nature and impact in secondary school pupils. J Child Psychol Psychiatry. 2008;49(4): 376-85.

24. van der Wal MF, de Wit CA, Hirasing RA. Psychosocial health among young victims and offenders of direct and indirect bullying. Pediatrics. 2003;111(6 Pt 1):1312-7.

25. Paul JJ, Cillessen AHN. Dynamics of peer victimization in early adolescence. J Appl Sch Psychol. 2003;19(2):25-43.

26. Qualter P, Brown SL, Munn P, Rotenberg KJ. Childhood loneliness as a predictor of adolescent depressive symptoms: an 8-year longitudinal study. Eur Child Adolesc Psychiatry. 2010;19(6):493-501.

27. Luk JW, Wang J, Simons-Morton BG. The co-occurrence of substance use and bullying behaviors among U.S. adolescents: understanding demographic characteristics and social influences. J Adolesc. 2012; 35(5):1351-60

28. Spriggs AL, Iannotti RJ, Nansel TR, Haynie DL. Adolescent bullying involvement and perceived family, peer and school relations: commonalities and differences across race/ethnicity. J Adolesc Health. 2007;41(3):283-93.

29. Mandrekar JN. Receiver operating characteristic curve in diagnostic test assessment. J Thorac Oncol. 2010;5(9):1315-6.

30. Heeringa S, West BT, Berglund PA. Applied survey data analysis. Boca Raton, Florida: Chapman and Hall/CRC; 2010.

31. Instituto Brasileiro de Geografia e Estatística. Síntese de indicadores sociais; uma analise das condições de vida da população brasileira 2016. Available from: http://biblioteca.ibge.gov.br/visualizacao/livros / liv98965.pdf Accessed on 14 June 2017.

32. Durand V, Hennessey J, Wells D, Crothers $\mathrm{L}$, Kolbert J. Bullying and substance use in children and adolescents. J Addict Res Ther. 2013;4:158.

33. Gaete J, Tornero B, Valenzuela D, RojasBarahona CA, Salmivalli C, Valenzuela E, et al. Substance use among adolescents involved in bullying: a cross-sectional multilevel study. Front Psychol. 2017;8:1056.

34. Luk JW, Wang J, Simons-Morton BG. Bullying victimization and substance use among U.S. adolescents: mediation by depression. Prev Sci. 2010;11(4):355-9.

35. Kaltiala-Heino R, Rimpela M, Rantanen $P$, Rimpela A. Bullying at school--an indicator of adolescents at risk for mental disorders. J Adolesc. 2000;23(6):661-74.

36. Revista Veja. Atirador de Realengo sofria bullying no colégio, diz ex-colega. Available from: https://veja.abril.com. $\mathrm{br} /$ brasil/atirador-de-realengo-sofria-bullyingno-colegio-diz-ex-colega/ Accessed on 10 August 2017.

37. Presidência da República, Casa Civil, Subchefia para Assuntos Jurídicos. Lei $\mathrm{n}^{\circ}$ 13.185, de 6 de novembro de 2015 . Vigência: Institui o Programa de Combate à Intimidação Sistemática (Bullying). Available from: http:/ / www.planalto.gov. br/CCIVIL_03/_Ato2015-2018/2015/ Lei/L13185.htm Accessed on 18 June 2017.

38. Van Ryzin MJ, Fosco GM, Dishion TJ. Family and peer predictors of substance use from early adolescence to early adulthood: an 11-year prospective analysis. J Addict Behav. 2012;37(12):1314-24.

39. Olweus D. Bullying at school. Basic facts and an effective intervention programme. Promot Educ. 1994;1(4):27-31, 48.

Manuscript received on 19 October 2017. Revised version accepted for publication on 25 March 2018. 
RESUMEN

\section{Participación en la acoso escolar y consumo de sustancias en estudiantes adolescentes brasileños}

Objetivo. Aunque la participación en el acoso escolar (bullying) se ha asociado con el consumo de sustancias en los adolescentes, la mayor parte de los datos científicos al respecto provienen de países de ingresos altos. Poco se sabe acerca del consumo de sustancias en los perpetradores y las víctimas en los países de ingresos bajos y medianos. En este estudio se explora la asociación entre algunos tipos de participación en el acoso escolar y el consumo de sustancias por los adolescentes en Brasil.

Métodos. Los datos para este estudio transversal provinieron de la Encuesta Nacional de Salud de los Escolares del 2015, una encuesta llevada a cabo en las escuelas a nivel nacional en los estudiantes brasileños del noveno curso. El consumo de sustancias se dividió en uso de una sola sustancia (a saber, consumo de alcohol, cigarrillos o marihuana en los 30 días anteriores) y uso concomitante (es decir, consumo de los tres tipos de sustancias). Se realizaron análisis de regresión logística y se calcularon las razones de posibilidades ajustadas (aOR), con ajustes para las características demográficas y la soledad de los estudiantes.

Resultados. Las probabilidades de consumo de cualquier sustancia en los perpetradores del acoso y los que eran a la vez perpetradores y víctimas, respectivamente, fueron más altas (con significancia estadística) en comparación con quienes no participaban en el acoso (aOR = 2,99, IC de 95\% =2,71-3,30; y aOR = 2,52, IC de 95\% = 2,31-2,75). Las probabilidades ajustadas de consumo concomitante de las sustancias también fueron significativamente más altas entre los perpetradores exclusivos y los perpetradores víctimas $(\mathrm{aOR}=4,04$, IC de 95\% = 3,05-5,35; y $\mathrm{RPa}=3,49$, IC de 95\% = 2,71-4,51, respectivamente). La victimización exclusiva se asoció con un aumento de $14 \%$ en las probabilidades de consumo de cualquier sustancia ( $\mathrm{aOR}=1,14$, IC de 95\% = 1,07-1,22). Conclusiones. Los resultados subrayan la compleja relación entre la participación de los adolescentes en el acoso y el consumo de sustancias. Los resultados también indican que deben tenerse en cuenta el tipo de participación en el acoso, así como los factores demográficos y psicológicos, al evaluar los comportamientos de riesgo para la salud de los adolescentes.

Palabras clave Adolescente; acoso escolar; trastornos relacionados con sustancias; Brasil. 
RESUMO Objetivo. Apesar de a prática de bullying ter sido associada ao uso de substâncias psicoativas em adolescentes, grande parte das evidências obtidas é oriunda de países de alta renda. Pouco se sabe sobre o uso de substâncias

\section{Prática de bullying e uso de substâncias psicoativas em estudantes adolescentes no Brasil} psicoativas em agressor-vítimas em países de baixa e média renda. O objetivo
deste estudo foi investigar a associação entre os tipos de prática de bullying e o uso de substâncias psicoativas em adolescentes no Brasil.

Métodos. Os dados para este estudo transversal foram obtidos da Pesquisa Nacional de Saúde do Escolar (PeNSE), um inquérito realizado com adolescentes do $9^{\circ}$ ano do ensino fundamental em todo o país. O uso de substâncias psicoativas foi analisado como sendo o uso de qualquer tipo de substância psicoativa (como uso de álcool, cigarros ou maconha nos 30 dias anteriores à pesquisa) e o uso concomitante de substâncias psicoativas (ou seja, uso dos três tipos de substâncias). Foram realizadas análises de regressão logística e calculadas razões de chances ajustadas (OR aj) segundo características demográficas e grau de solidão dos estudantes.

Resultados. As chances de uso de qualquer tipo de substância psicoativa entre os exclusivamente praticantes de bullying e agressor-vítimas foram significativamente maiores em comparação aos que não praticam bullying (OR aj = 2,99, IC 95\% = 2,713,30 e OR aj $=2,52$, IC 95\% = 2,31-2,75, respectivamente). As chances ajustadas do uso concomitante de substâncias psicoativas foram também significativamente maiores entre os exclusivamente praticantes de bullying e agressor-vítimas (OR aj =4,04, IC $95 \%=3,05-5,35$ e OR aj = 3,49, IC 95\% = 2,71-4,51, respectivamente). Exclusivamente vitimização foi associado a uma chance $14 \%$ maior de uso de qualquer tipo de substância psicoativa (OR aj = 1,14, IC 95\% = 1,07-1,22).

Conclusões. Os resultados deste estudo chamam atenção à complexa relação entre a prática de bullying e o uso de substâncias psicoativas em adolescentes. Os achados do estudo também indicam que o tipo de prática de bullying e fatores demográficos e psicológicos devem ser considerados ao serem avaliados os comportamentos de risco à saúde dos adolescentes.

Palavras-chave Adolescente; bullying; transtornos relacionados ao uso de substâncias; Brasil. 